\title{
Społeczne inicjatywy na rzecz organizacji opieki socjalnej nad ludźmi starymi w Królestwie Polskim na przelomie XIX i XX wieku. Zarys problematyki
}

\begin{abstract}
Social initiatives for the organisation of social protection of the elderly in the Kingdom of Poland in the late $19^{\text {th }}$ and the early $20^{\text {th }}$ centuries: an outline of issues

Lack of a universal pension system in the Kingdom of Poland in the late $19^{\text {th }}$ and the early $20^{\text {th }}$ centuries was one of the factors contributing to the difficult situation of the elderly from non-elite social strata, particularly in the face of insufficient support of the families. The homeless, who often also suffered from diseases, were crippled and begged, found themselves in a particularly difficult situation, men and women alike. Organising institutional social protection and medical care for this group required instant action. The priority was to establish homes for old people and various types of residential homes. This was primarily handled by charities for which medical care and welfare of the elderly were among the most important areas of activity. Old people's homes were also established by religious communities and individualsas well as institutions operating on a self-help basis.
\end{abstract}

Keywords: social care, old people' homes, self-help activity, Kingdom of Poland

Zapewnienie opieki ubogim osobom starym było od wieków jednym z najważniejszych zadań organizacji dobroczynnych ${ }^{1}$. Przemiany społeczno-gospodarcze i kulturowe, związane z industrializacją i urbanizacją, przyczyniały się do wzrostu potrzeb w zakresie

1 Syntezujące spojrzenie na sytuację ludzi starych w Polsce na przestrzeni wieków przedstawiła M. Stawiak-Ososińska, The History of Old Age in Poland (Outline), w: Situation, Education and Activation of Elderly People in Europe, red. M. Stawiak-Ososińska, S. Chrost, Kielce 2014, s. 26-51. Zob. także K. Kabacińska, K. Ratajczak, Obraz starości w piśmiennictwie polskim od czasów średniowiecza po wiek XVIII, w: Starość w perspektywie studiów pedagogicznych, red. A. Tokaj, Leszno 2008, s. 13-30. Szczególnie wartościowym opracowaniem zbiorowym dotyczącym starości na ziemiach polskich w epoce nowożytnej i najnowszej jest: 
instytucjonalizacji pomocy dla osób z najuboższych środowisk. U schyłku XIX i na początku XX w. procesy takie były widoczne w Królestwie Polskim². Wobec braku powszechnego systemu ubezpieczeń i świadczeń emerytalnych w Królestwie do I wojny światowej większość osób z nieelitarnych środowisk w podeszłym wieku znajdowała się w trudnym położeniu ekonomicznym. W szczególnie ciężkiej sytuacji byli ubodzy seniorzy, którzy nie mieli rodzin. Samotność pogłębiała trudności socjalno-bytowe, a w połączeniu ze złym stanem zdrowia była czynnikiem sprzyjającym skrajnemu ubóstwu. Oczywiście posiadanie rodziny nie zawsze chroniło przed osamotnieniem, nędzą i zaniedbaniem, a czasami było również przyczyną doświadczania przemocy ${ }^{3}$. Przebywająca w warszawskim areszcie staruszka twierdziła: „lepiej tu niż w domu - mniej biją, jeść dają"4.

Celem niniejszego artykułu jest przedstawienie instytucjonalnych form opieki nad ludźmi starymi w Królestwie Polskim na przełomie XIX i XX w. (z racji rozległości tematu nie uwzględniono działających w Królestwie rosyjskich, szwajcarskich i czeskich zakładów dla seniorów). Pozwoli to na dokonanie rekonstrukcji sieci placówek, udzielających pomocy socjalnej i medycznej osobom starszym oraz umożliwi wstępne oszacowanie okoliczności i zakresu ich działalności.

W 1897 r. na łamach czasopisma „Ateneum” Ludomir Grendyszyński pisał o ubogich, bezdomnych i żebrzących starcach, którzy na czas zimowych miesięcy prosili o przyjęcie do warszawskich szpitali zaznaczając, że

ubodzy tej kategorii przyjęci do szpitala być nie mogą, nie powinni. A jednak są przyjmowani i nie bywają wydalani, pomimo stwierdzenia nieuleczalności, po prostu dlatego, że lekarz często nie ma serca wyrzucić na bruk biedaka, który choć nie potrzebuje właściwego leczenia, ale potrzebuje przecież opieki i który nie ma gdzie się podziać. Więc wielu z nich zimuje corocznie w szpitalu, dopóki ciepłe promienie wiosennego słońca nie wywabią ich na powietrze, teraz już nieco miłosierniejsze dla nędzarzy ${ }^{5}$.

Ludzie starzy i starość na ziemiach polskich od XVIII do XXI wieku (na tle porównawczym), t. I-II, red. A. Janiak-Jasińska, K. Sierakowska, A. Szwarc, Warszawa 2016.

2 Równolegle rozwój nauki przyczynił się do wzrostu zainteresowania problemami starzenia się i starości. Na przełomie XIX i XX w. o sytuacji ludzi starych pisali m.in. lekarze i ekonomiści. Zob. np. W. Wścieklica, Państwowe kasy ubezpieczenia robotników na wypadek starości i nieudolności do pracy oraz nowe projekty przymusowego w nim udziału we Francyi, Anglii i Niemczech, „Ateneum” 1888, t. IV, z. 10, s. 139-158, t. IV, z. 11, s. 300-320; J. Stella-Sawicki, Czerstwa starość, czyli jak zachować zdrowie do późnego wieku, Warszawa 1901. W historiografii warto wyróżnić opracowania: M. Nawrot-Borowska, ,Życie dtugie i starość zdrowa”: w świetle poradników z zakresu higieny i lecznictwa z II połowy XIX i początków XX wieku, w: Historyczno-społeczne aspekty starzenia się i starości, red. M. Stawiak-Ososińska, A. Szplit, Kielce-Włocławek 2014, s. 38-64; B. Urbanek, Medycyna a starość i choroby ludzi w podeszlym wieku na przełomie XIX i pierwszego półwiecza XX wieku (zarys problematyki i potrzeby badawcze), w: Ludzie starzy..., t. I, s. 83-95.

${ }^{3}$ Zob. szerzej T. Kalniuk, Mityczni obcy: dzieci i starcy w polskiej kulturze ludowej przełomu XIX $i$ XX wieku, Toruń 2014.

${ }^{4}$ S. Sempołowska, Z dna nędzy, w: Publicystyka społeczna, red. Ż. Kormanowa, Warszawa 1960, s. 22.

${ }^{5}$ L. Grendyszyński, Opieka nad biednymi i domy schronienia, „Ateneum” 1897, t. III, z. 8, s. 204. Por. E. Mazur, Szpitale w Królestwie Polskim w XIX wieku, Warszawa 2008, s. 139; A. Wejssel, W sprawie działalności sanitarnej gmin słów kilka, „Zdrowie” 1912, nr 7, s. 536. 
Opisując problem ubogich starców, którzy nie mając dachu nad głową, szukali schronienia w szpitalach, L. Grendyszyński podkreślał potrzebę zapewnienia tej grupie ludzi pomocy socjalnej i zdrowotnej zarazem, w myśl zasady senectus ipsa est morbus. Wielu publicystów wypowiadających się na temat położenia seniorów z ubogich warstw starość traktowało synonimicznie $\mathrm{z}$ pojęciami choroby i niedołężności. Było to przejawem uproszczeń i stereotypów w postrzeganiu osób w podeszłym wieku, ale w odniesieniu do wielu ubogich, niedożywionych, przemęczonych, żyjących w trudnych warunkach seniorów zły stan zdrowia był faktem. Kłopoty zdrowotne dotyczyły z pewnością większości byłych pracowników przemysłowych ${ }^{6}$.

Pomoc lekarską i pielęgniarską oraz wsparcie materialne i duchowe ubogim chorym, w tym osobom starszym, zapewniały rozmaite organizacje społeczne (w niniejszym tekście nie porusza się kwestii opieki nad chorymi psychicznie). Opiekę nad ubogimi chorymi sprawowały funkcjonujące na zasadach dobroczynnych, a od początku XX w. coraz częściej także samopomocowych, organizacje katolickie, ewangelickie i żydowskie ${ }^{7}$. Ich działalność pomocowa obejmowała różne grupy ludności. W odniesieniu do części placówek niedostatki zachowanych danych źródłowych uniemożliwiają określenie, jaką część spośród podopiecznych tych organizacji stanowiły osoby starsze. W wielu jednak wypadkach wiadomo, że byli oni jedną z liczniejszych grup korzystających.

Ważną rolę w zapewnianiu potrzebującym opieki medycznej odegrały ukryte zgromadzenia zakonne. W miejskich przytułkach, ambulatoriach i szpitalach, m.in. w Warszawie, Łodzi, Lublinie, Pabianicach, Tomaszowie Mazowieckim, Kozienicach pracowały członkinie Zgromadzenia Sióstr Franciszkanek od Cierpiących (franciszkanki) ${ }^{8}$. Członkinie zgromadzeń bezhabitowych - np. ze Zgromadzenia Sióstr Służek NMP Niepokalanej opiekowały się chorymi także w ich domach. Wielu przewlekle i ciężko chorych podopiecznych było ludźmi w podeszłym wieku9. Istotną rolę $\mathrm{w}$ opiece nad chorymi w ich domach pełniły także członkinie Towarzystwa Pań Miłosierdzia św. Wincentego à Paulo, działającego w Warszawie, Płocku, Pułtusku, Radomiu, Siedlcach, Tarczynie i Piotrkowie ${ }^{10}$.

${ }^{6}$ Por. A. Gotowicz, Wplyw warunków pracy na stan zdrowia robotników przemysłowych $w$ guberni piotrkowskiej w 2. połowie XIX i na początku XX w., „Roczniki Dziejów Społecznych i Gospodarczych” 2013, t. LXXIII, s. 123-152.

${ }^{7} \mathrm{Na}$ początku XX w. zalegalizowano wiele żydowskich towarzystw, mających na celu zapewnienie współwyznawcom opieki medycznej. Najwięcej ich powstało w guberni piotrkowskiej. J. Fijałek, J. Indulski, Opieka zdrowotna w Łodzi do roku 1945. Studium organizacyjno-historyczne, Łódź 1990, s. 115; K. Badziak, J. Walicki, Żydowskie organizacje społeczne w Łodzi (do 1939 r.), Łódź 2002, s. 127-133, 136-141.

${ }^{8}$ M.H. Mazurek, Powstanie i rozwój ukrytych zgromadzeń bt. Honorata Koźmińskiego w latach 18741908, Sandomierz 2009, s. 273-274.

9 Ibidem, s. 256-269.

${ }^{10}$ B. Urbanek, Idea opieki nad chorym na ziemiach polskich $w$ latach 1809-1914, Wrocław 2001, s. 281; Kalendarz ziemi radomskiej, Radom 1912, s. 231; Kalendarz informacyjno-encyklopedyczny na rok zwyczajny 1913, Warszawa 1913, s. 504. 
W Warszawie opiekę medyczną najuboższym mieszkańcom zapewniało założone w 1898 r. Towarzystwo Opieki nad Nieuleczalnymi Chorymi. Prócz prowadzenia ambulatoriów i przytułków celem towarzystwa było udzielanie bezpłatnej pomocy lekarskiej i pielęgniarskiej ubogim chorym $\mathrm{w}$ ich domach, udzielanie wsparcia w postaci odzieży, żywności i zapomóg ${ }^{11}$. Starcy korzystali z wielu innych warszawskich instytucji, powołanych i funkcjonujących z myślą o osobach chorych, nie mogących samodzielnie zapewnić sobie opieki i pielęgnacji. Seniorzy stanowili znaczącą grupę wśród podopiecznych tego rodzaju zakładów. Pomocy w czasie choroby szukano zatem w przytułku św. Salezego, założonym podczas epidemii cholery w $1885 \mathrm{r}^{12}$, w utworzonym w $1894 \mathrm{r}$. zakładzie św. Antoniego dla starców i kalek obojga płci, w działającym od 1888 r. przytułku św. Stanisława Kostki; ten ostatni przyjmował nieuleczalnie chore kobiety ${ }^{13}$. Tylko kobietom udzielało wsparcia założone w 1858 r. schronisko „Przytulisko”"14. Dla nieuleczalnie chorych obu płci przeznaczone było Schronienie dla Nieuleczalnych Paralityków, znajdujące się przy ul. Nowowiejskiej 32. Zostało otwarte 12 czerwcu 1875 r., ale wcześniej chorzy znajdowali się pod opieką wdowy po Antonim Piłsudskim, Izabelli z Orłowskich. W latach 80. XIX w. z opieki zakładu korzystało kilkadziesiąt osób. W $1881 \mathrm{r}$. utworzono Schronienie dla Paralityków Świętego Władysława ${ }^{15}$. Było przeznaczone dla 12 sparaliżowanych chorych; część opłacała swój pobyt, część przebywała na koszt zakładu. Od 1894 r. istniał przytułek dla chorych nieuleczalnych rakowatych (kobiet i dziewcząt). W latach 1894-1898 funkcjonował on jako Dom św. Józefa przy ul. Wspólnej 69. W październiku 1898 r. przeniesiono go do mieszczącego się przy ul. Puławskiej budynku zwanego „Królikarnią”. Odtąd przytułek nazywano „Królikarnią”. Mieścił 45 łóżek $^{16}$.

Czasową opiekę nad osobami, które nie mogły wykonywać pracy ani mieszkać samodzielnie z powodu rekonwalescencji po pobycie w szpitalu, zapewniał założony w $1870 \mathrm{r}$. Przytułek dla Rekonwalescentów (nazywany także Przytułkiem dla Biednych Wychodzących ze Szpitala) ${ }^{17}$. Najpierw mieścił się przy ul. Ogrodowej, później zyskał nową siedzibę przy ul. Dzikiej ${ }^{18}$. Wśród korzystających byli również seniorzy. Do przytułku trafiali chrześcijanie i Żydzi. W 1875 r. z przytułku korzystało 430 chrześcijan i 662

11 Towarzystwo opieki nad nieuleczalnymi chorymi, „Zdrowie” 1898, z. 5, s. 298.

${ }^{12}$ L. Grendyszyński, op. cit., s. 206; H. Markiewiczowa, Działalność opiekuńczo-wychowawcza Warszawskiego Towarzystwa Dobroczynności 1814-1914, Warszawa 2002, s. 118.

${ }_{13}$ Zaktad dla kalek siostry Julii, „Kronika Rodzinna” 1895, nr 7, s. 194-196; Niemiłosierne miłosierdzie, „Kronika Rodzinna” 1896, nr 8, s. 226.

14 Silva Rerum, „Kronika Rodzinna” 1891, nr 4, s. 127.

15 Kalendarz informacyjno-encyklopedyczny na rok zwyczajny 1914, Warszawa 1914, s. 549.

${ }^{16}$ Archiwum Główne Akt Dawnych, Kancelaria Generał-Gubernatora Warszawskiego, sygn. 7664; Kalendarz... na rok 1914, s. 548.

${ }^{17}$ F. Fryze, I. Chodorowicz, Przewodnik po Warszawie i jej okolicach, Warszawa 1873, s. 395.

${ }_{18}$ H. Markiewiczowa, op. cit., s. 117. 
starozakonnych, w 1890 r. 610 chrześcijan (w tym 446 mężczyzn i 173 kobiety) i 220 starozakonnych (171 mężczyzn i 59 kobiet) ${ }^{19}$. Mankamentem był krótki czas gwarantowanej opieki - pensjonariusz nie mógł przebywać w placówce dłużej niż tydzień. Przyjmowano do niej tylko osoby najuboższe, bezpłatnie leczone w szpitalu. Na początku XX w. w Warszawie założono kilka kolejnych przytułków dla starców i chorych. Były to m.in. „Dźwignia” - schronienie dla biednych, przy ul. Szczygła 3/5, przytułek „Betania” przy ul. Chmielnej, przytułek Świętego Wincentego à Paulo przy ul. Ordynackiej 4 oraz schronienie dla starców przy ul. Wilczej $7^{20}$.

Wsparcia chorym i ubogim w Warszawie udzielało także Biuro Nędzy Wyjątkowej. Organizowało doraźną pomoc materialną, zbierało dary. Współpracowało z aptekami, wydającymi ubogim, na podstawie recept poświadczonych przez Biuro, bezpłatne lekarstwa. Skala pomocy w tym zakresie nie była jednak duża, skoro w 1879 r., w ciągu 12 miesięcy, na lekarstwa dla ubogich wydano zaledwie 30 rubli. Współpracowano także z lekarzami, zapewniającymi bezpłatną pomoc tym, „których szpitale albo pomieścić nie są w stanie lub z powodu chorób chronicznych przyjąć nie mogą"21. Wśród osób wymagających pomocy i wspieranych przez Biuro Nędzy Wyjątkowej było wielu starców. Organizacja zamieszczała w prasie informacje o osobach szczególnie potrzebujących, zbierając na ich rzecz darowizny. I tak na przykład w 1870 r. wśród ludzi w najtrudniejszym położeniu wymieniano m.in. wdowy mające na utrzymaniu kilkoro dzieci, osoby bardzo chore i kalekie oraz osoby starsze, znajdujące się w skrajnie trudnym położeniu. Byli wśród nich m.in.: niewidoma, niezdolna do pracy 68-letnia Petronela Chudzińska, 75-letnia wdowa Marianna Ignarska, chorująca 70-letnia wdowa Balbina Pierkowska, 78-letnia wdowa Maria Kazanecka ,z powodu starości niezdolna do pracy”, 60-letnia Estera Mordkowa, „kaleka, niezdolna do pracy”, 60-letnia Krystyna K., niemająca rodziny kaleka oraz ,Juchet z żoną, starzy, po lat 75, chorzy, córka kaleka, wielka nędza"22.

Pomoc medyczną dla ubogich organizowały organizacje dobroczynne w całym Królestwie. Osoby starsze należały do ich beneficjentów. W wielu organizacjach wyznaczano osobne sekcje pomocy lekarskiej. Tak było np. w Warszawskim Towarzystwie Dobroczynności, w Kaliskim Towarzystwie Dobroczynności oraz w Katolickim Towarzystwie Dobroczynności w Łęczycy ${ }^{23}$. W niektórych organizacjach nie tworzono odrębnej komórki, ale dążono do zapewniania ubogim bezpłatnych porad lekarskich

19 Silva Rerum, „Kronika Rodzinna” 1891, nr 8, s. 255.

${ }^{20}$ Prócz tego działał także przytułek prowadzony przez Rosyjskie Towarzystwo Dobroczynności przy ul. Franciszkańskiej 2 oraz przytułek dla biednych poddanych austro-węgierskich na rogu ul. Inżynierska i Małej. Kalendarz... na rok zwyczajny 1913, op. cit., s. 492.

${ }^{21}$ Roczne sprawozdanie z czynności Biura Informacyjnego o nędzy wyjątkowej od I-go stycznia 1879 r., po I-wszym stycznia 1880 r., „Przegląd Katolicki” 1880, nr 12, s. 205.

22 Biuro Informacyjne o nędzy wyjątkowej, „Przegląd Katolicki” 1870, nr 36, s. 576.

${ }^{23}$ H. Markiewiczowa, op. cit., s. 214-221; A. Tomaszewicz, Dobroczynność w guberni kaliskiej 18641914, Łódź 2010, s. 116; Kalendarz... na rok 1914, op. cit., s. 555-556. 
i lekarstw. Mówiły o tym statuty i inne dokumenty organizacji, jak np. Piotrkowskiego Towarzystwa Dobroczynności ${ }^{24}$. W niektórych miastach, jak w Łodzi, powstały odrębne stowarzyszenia zajmujące się organizowaniem pomocy ubogim chorym. W $1906 \mathrm{r}$. utworzono Łódzkie Towarzystwo przy Domu Miłosierdzia Warszawskiego Ewangelicko-Augsburskiego Okręgu Konsystorskiego, w 1912 r. Łódzkie Ewangelicko-Augsburskie Towarzystwo Dobroczynności „Betleem” oraz Łódzkie Ewangelicko-Baptystyczne Towarzystwo Dobroczynności „Wifleem”25. Osoby starsze (choć nie tylko one) korzystały z porad udzielanych w organizowanych ze środków społecznych ambulatoriach. Działały one w największych miastach Kongresówki. Najlepiej tego rodzaju opieka medyczna funkcjonowała w Warszawie, Łodzi i Lublinie. Były zakładane przez towarzystwa dobroczynne i inne organizacje społeczne. Zazwyczaj za poradę medyczną pobierano niewielką opłatę, niekiedy za darmo wydawano leki, środki opatrunkowe i żywność, pełniono nocne dyżury przy chorych. Najbiedniejszych chorych, w tym starców, przyjmowano czasami bezpłatnie; najbardziej potrzebującym udzielano drobnych zasiłków pieniężnych ${ }^{26}$.

Doraźne wsparcie socjalne i zdrowotne często było niedostateczną formą pomocy. Wielu najuboższych starców, nie mając źródeł utrzymania, dachu nad głową i wsparcia bliskich, wymagało opieki całościowej. W ostatnich dekadach XIX w. i na początku XX w. znacznie wzrosła liczba miejsc w funkcjonujących głównie na zasadach filantropijnych przytułkach. Nadal jednak zapewniało to opiekę tylko niewielkiej części potrzebujących. Tworzenie zakładów dla osób starych, chorych i niepełnosprawnych było jednym z najważniejszych zadań, jakie stawiały sobie towarzystwa dobroczynne. Zazwyczaj w pierwszym okresie działalności, po zgromadzeniu środków finansowych, przystępowano do założenia placówki zapewniającej stały pobyt niemającym środków do życia starcom i osobom przewlekle chorym. Zakłady takie nazywano zazwyczaj przytułkami dla starców i kalek. Najwięcej miejsc zapewniały placówki prowadzone przez organizacje dobroczynne w dwóch największych miastach Królestwa - Warszawie i Łodzi. Większość warszawskich przytułków działała (stale lub przejściowo) pod auspicjami Warszawskiego Towarzystwa Dobroczynności. Największy zakład rozpoczął działalność w 1815 r. Kilkakrotnie zmieniał siedzibę, by ostatecznie znaleźć trwałe miejsce w byłym klasztorze karmelitanek przy Krakowskim Przedmieściu, z czasem rozbudowanym na potrzeby placówki. W lipcu 1887 r. utworzono drugi dom, który planowano umieścić w budynku przy ul. Freta. Trudności finansowe i organizacyjne zmusiły władze Towarzystwa do umieszczenia przytułku w gmachu głównym, przy

\footnotetext{
${ }^{24}$ Archiwum Państwowe w Piotrkowie Trybunalskim, Piotrkowskie Towarzystwo Dobroczynności dla Chrześcijan, sygn. 23.

25 S. Pytlas, Łódzka burżuazja przemysłowa w latach 1864-1914, Łódź 1994, s. 175.

26 W. Berner, J. Supady, Działalność lekarsko-społeczna na rzecz zdrowia publicznego w Łodzi w latach 1870-1914, Łódź 2001, s. 207-208; M. Hanecki, Z dziejów warszawskiej służby zdrowia w l. 18631900, w: Warszawa popowstaniowa 1864-1918, red. S. Kalabiński, R. Kołodziejczyk, Warszawa 1968, s. $105-113$.
} 
Krakowskim Przedmieściu. Przeciętnie w obu zakładach przebywało około 350-400 osób rocznie ${ }^{27}$. Opiekę nad starcami i chorymi w Warszawie zapewniano także w zakładach o charakterze wyznaniowym. Od 1820 r. do I wojny światowej funkcjonował Zakład pod wezwaniem Świętego Ducha i Najświętszej Marii Panny, przy ul. Przyrynek $4^{28}$. W 1842 r. dom starców, kalek i nieuleczalnych założyła warszawska gmina ewangelicka ${ }^{29}$. Część pensjonariuszy przebywała w zakładzie bezpłatnie, w części przypadków za pobyt krewnego płaciła rodzina. W 1906 r. na 184 osoby tylko 48 płaciło za miejsce w schronisku ${ }^{30}$. Pobyt pozostałych starców finansowano ze środków gminy. W 1900 r. przy ul. Leszno 20 dom dla starców i kalek dysponujący 10 stałymi miejscami utworzył Zbór Ewangelicko-Reformowany. Gmina żydowska od $1840 \mathrm{r}$. prowadziła przytułek zwany Głównym Domem Schronienia Starców, Sierot i Paralityków Starozakonnych, znajdujący się przy ul. Wolskiej. Początki zakładu sięgały 1840 r., na początku XX w. utrzymywano w nim 140 stałych miejsc ${ }^{31}$.

W Łodzi główne schronisko dla starców obu płci, będących chrześcijanami, zostało założone w 1886 r. przez Łódzkie Chrześcijańskie Towarzystwo Dobroczynności Przyjmowało osoby mające więcej niż 50 lat, od co najmniej 5 lat mieszkające w Łodzi, niemające żadnej pomocy ze strony krewnych. W pierwszym okresie mieściło się w prywatnym domu przy ul. Cegielnianej 44 (dziś ul. Jaracza), później przeniesiono je do większego budynku przy tej samej ulicy. W 1897 r., po długich staraniach i pracach, oddano do użytku nowy budynek przytułku, stanowiący własność Towarzystwa, przy ul. Dzielnej (obecnie ul. Narutowicza). W pierwszym roku działalności łódzkiego przytułku przyjęto do niego 54 osoby, w późniejszych latach liczba ta szybko rosła w 1893 r. było to 79 osób, w 1895 r. 83. Po oddaniu do użytku nowego gmachu przytułku liczba pensjonariuszy wynosiła rocznie od 147 w 1897 r., 237 w 1900 r., 266 w 1905 r., 294 w 1910 r. do 309 w 1914 r. ${ }^{32}$ Osoby starsze korzystały także z opieki w ewangelickim Przytułku dla Niedorozwiniętych i Epileptyków, działającym najpierw w Wiskitkach, później w Łodzi ${ }^{33}$. Opiekę nad ubogimi starcami w Łodzi organizowali także członkowie społeczności żydowskiej. W 1893 r. władze zatwierdziły statut fundacji „Dom Ubogich w Łodzi”, założonej przez Hermana Konstadta, który po

${ }^{27}$ Szerzej zob. H. Markiewiczowa, op. cit., s. 101-114; E. Mazur, Dobroczynność w Warszawie w XIX wieku, Warszawa 1999, s. 58-59; eadem, Opieka dobroczynna nad starcami $w$ Warszawie $w$ drugiej połowie XIX wieku, „Kwartalnik Historii Kultury Materialnej” 2010, t. 58, z. 1, passim.

${ }^{28}$ Dom Schronienia przy Kościele Panny Maryi w Warszawie, „Kronika Rodzinna” 1877, nr 5, s. 69-70; Ż. Grotowski, Rozwój zakładów dobroczynnych w Warszawie, Warszawa 1910, s. 132.

${ }^{29}$ F. Fryze, I. Chodorowicz, op. cit., s. 401.

30 Sprawozdanie roczne z naszych zakładów..., op. cit., s. 177-179.

${ }^{31}$ Kalendarz... na rok 1913, op. cit., s. 492; F. Fryze, I. Chodorowicz, op. cit., s. 402-403.

32 J. Sosnowska, Działalność socjalna i opiekuńczo-wychowawcza Łódzkiego Chrześcijańskiego Towarzystwa Dobroczynności (1885-1940), Łódź 2011, s. 102.

${ }_{33}$ R. Gundlach, Dom Miłosierdzia, „Zwiastun Ewangeliczny” 1898, nr 8, s. 179; Dom Miłosierdzia, „Zwiastun Ewangeliczny” 1904, nr 4, s. 121. 
zakupieniu w 1889 r. posesji przy ul. Średniej 54 (obecnie ul. Pomorska) rozbudował istniejący tam budynek i dostosował go do potrzeb przytułku dla ubogich starców i kalek obu płci wyznania mojżeszowego. Początkowo przytułek był przeznaczony dla 14 osób, po rozbudowie został dostosowany do przyjęcia ponad 30 osób, a w 1902 r. przebywało w nim 50 starców $^{34}$. Osoby starsze korzystały też z przytułku dla osób kalekich, założonego przez Łódzkie Żydowskie Towarzystwo Dobroczynności. Zakład zapewniał podopiecznym darmowy pobyt, wyżywienie i opiekę lekarską. Przeciętnie przebywało w nim 12-14 osób ${ }^{35}$.

Poza przedstawionymi przytułkami, działającymi w Warszawie i Łodzi, w Królestwie Polskim na przełomie XIX i XX w. zakłady dla osób starszych i niedomagających działały we wszystkich miastach gubernialnych i w wielu mniejszych ośrodkach miejskich. Najwięcej przytułków funkcjonowało w guberni warszawskiej. Na początku XX w. poza Warszawą i Łodzią przytułki zapewniające stałe schronienie dla osób w podeszłym wieku znajdowały się w następujących miejscowościach ${ }^{36}$ :

- gubernia warszawska - Brześć Kujawski, Dąbrowice, Grójec, Gostynin, Iłów, Kłotno, Kowal, Łowicz, Mińsk Mazowiecki, Nieszawa (2 przytułki), Płońsk, Pułtusk, Sarbiew, Skierniewice, Szymanów, folwark Tułowice, Włocławek (3 przytułki - w tym ewangelicki),

- gubernia kaliska - Dąbie, Grabów, Kalisz (3 przytułki, w tym żydowski), Koło, Konin, Łęczyca, Sieradz, Słupca, Turek, Warta, Wieluń, Zduńska Wola,

- gubernia kielecka - Chęciny, Kielce, Miechów, Nowy Korczyn, Olkusz, Pilica, Pińczów,

- gubernia lubelska - Kraśnik, Lublin (5 przytułków - w tym żydowski), Chełm, Biłgoraj, Hrubieszów, Kryłów, Krasnostaw, Tomaszów (przytułek chrześcijański i żydowski), Zamość (przytułek chrześcijański i żydowski), Wrzelowiec, kocin,

- gubernia łomżyńska - Łomża (przytułek chrześcijański i żydowski), Ostrołęka, Ty-

- gubernia piotrkowska - Będzin (przytułek chrześcijański i żydowski), Brzeziny, Częstochowa (przytułek chrześcijański i żydowski), Dąbrowa Górnicza ${ }^{37}$, Łask, NowoRadomsk, Pabianice, Piotrków (przytułek chrześcijański i żydowski), Zgierz,

- gubernia płocka - Dobrzyń, Lipno, Mława, Płock (2 przytułki chrześcijańskie i 1 żydowski), Sierpc, Wyszogród,

- gubernia radomska - Sandomierz, Staszów, Opoczno, Radom (3 przytułki - w tym 1 dla bezdomnych i umysłowo chorych), Rożki Wieś, Włostów,

${ }^{34}$ W. Puś, Żydzi w Łodzi w latach zaborów 1793-1914, Łódź 2003, s. 192-193; K. Badziak, J. Walicki, op. cit., s. 207-209.

${ }^{35}$ K. Badziak, J. Walicki, op. cit., s. 89; Czas. Kalendarz na rok 1914, Łódź 1913, dział c, s. 73.

36 Nazwy miejscowości zostały podane w formie stosowanej w omawianym okresie.

${ }^{37}$ Przytułek dla starców we wsi Reden utrzymywany przez Towarzystwo Pomocy dla Biednych Chrześcijan w Dąbrowie Górniczej. 
- gubernia siedlecka - Międzyrzec, Siedlce, Żelechów,

- gubernia suwalska - Suwałki (przytułek chrześcijański i żydowski), Sejny ${ }^{38}$.

Dokładne ustalenie liczby przytułków i ich lokalizacji jest dziś trudne. Obok towarzystw dobroczynnych i związków religijnych pomoc dla starców i chorych, którzy z przyczyn niezależnych od siebie znaleźli się w trudnej sytuacji życiowej, organizowały osoby prywatne, w tym m.in. zamożni ziemianie i właściciele wielkich fabryk. I tak na przykład w Łodzi przytułek dla starców mieścił się przy szpitalu fabrycznym Karola Scheiblera $^{39}$. Podobny zakład dla starców zbudowali na początku XX w. w Sosnowcu bracia Franz i Ernst Schön. Dom starców funkcjonował także w osadzie fabrycznej Żyrardó ${ }^{40}$. Wymienione placówki nie zostały uwzględnione w wykazie miejscowości zamieszczonym wyżej. Niekiedy organizowanie różnego rodzaju działań socjalnych i opiekuńczych utrzymywano w tajemnicy $\mathrm{z}$ obawy przed represjami władz. Dotyczyło to głównie zakładów prowadzonych przez członkinie ukrytych zgromadzeń zakonnych. Pracowały one w przytułkach prowadzonych przez organizacje społeczne, czasem prowadziły zakład założony przez zgromadzenie bądź ufundowany przez prywatnego darczyńcę. Niektóre z nich funkcjonowały przez długi czas, niektóre zostały zlikwidowane jeszcze u schyłku XIX w. Przykładem zakładu, który nie przetrwał do XX w., jest przytułek dla staruszek w Zakroczymiu, działający w latach 1881-1893, prowadzony przez Zgromadzenie Córek Matki Bożej Bolesnej (serafitki).

Osobną kategorią placówek całościowej opieki nad ludźmi starszymi były zakłady przeznaczone dla konkretnych grup zawodowych. Warszawskie Towarzystwo Dobroczynności założyło w 1893 r. Schronienie dla Starych Szwaczek. Przebywało w nim kilkadziesiąt kobiet, które częściowo same zarabiały na własne utrzymanie, wykonując w miarę możliwości drobne prace krawieckie ${ }^{41}$. W 1898 r., z inicjatywy szewca i właściciela składu skór Marcelego Kłyszewskiego, Warszawskie Towarzystwo Dobroczynności założyło Schronisko dla Rzemieślników i Robotników Fabrycznych. Przyjmowano do niego mieszkających w Warszawie chrześcijan powyżej 60. roku życia; młodsi mogli w nim przebywać tylko wówczas, gdy kalectwo uniemożliwiało im pracę. Część pensjonariuszy wpłacała jednorazową opłatę wpisową w wysokości 500 rubli, część corocznie

${ }^{38}$ Dom Miłosierdzia we Włocławku, „Zwiastun Ewangeliczny” 1909, nr 2, s. 52-53; Kalendarz... na rok 1913, op. cit., s. 493-495; Kalendarz na rok... 1914, op. cit., s. 549-551, 555-558; J. Zawadzki, Potrzeby naszych miast i miasteczek. Miasta nasze $w$ świetle ankiety, „Zdrowie” 1912, nr 3, s. 201; nr 6, s. 504, nr 7, s. 556, 558; M. Certowicz, Opis Włocławka pod względem sanitarnym i hygienicznym, „Zdrowie” 1912, nr 6, s. 488; J. Kłaczkow, Historia parafi ewangelicko-augsburskiej w Radomiu, Toruń 2005, s. 32; A.J. Papierowski, Okoliczności utworzenia w Płocku Towarzystwa Dobroczynności i jego działalność do wybuchu I wojny światowej, „Notatki Płockie” 2009, nr 1, s. 25; M.H. Mazurek, op. cit., s. 268, 272, 293, 294; S. Stampfer, Nowoczesna opieka społeczna i samotni seniorzy: dzieje żydowskich domów starców, w: Ludzie starzy i starość..., t. I, s. 361.

39 J. Fijałek, J. Indulski, op. cit., s. 171.

40 A. Gryciuk, Rozwój przestrzenny osady fabrycznej w Żyrardowie w latach 1829-1916, „Rocznik Mazowiecki” 1976, nr 7, s. 127-166.

${ }^{41}$ H. Markiewiczowa, op. cit., s. 114. 
wpłacała 100 rubli, pobyt najuboższych opłacali ich byli pracodawcy lub inni darczyń$\mathrm{cy}^{42}$. Wśród podopiecznych byli ludzie różnych zawodów, m.in. kowale, szewcy, garbarze, stolarze, młynarze, rzeźnicy, cukiernicy.

Na przełomie XIX i XX w. założono kilka przytułków dla starych sług, niezdolnych do pracy zarobkowej. Od 1896 r. w Warszawie przy ul. Bednarskiej działał przytułek dla sług św. Zyty przeznaczony dla starców ${ }^{43}$. Podobne schronisko pod egidą Kieleckiego Towarzystwa Dobroczynności założono w 1896 r. w Kielcach. W 1909 r. zostało ono przeniesiono do nowego budynku i przeszło pod kuratelę Stowarzyszenia Katolickich Służących św. Zyty ${ }^{44}$. Mieszkańcy zakładu prowadzili stołówkę, pralnię i szwalnię, a dochody z tej działalności pokrywały koszty utrzymania. W 1905 r. w Lublinie otwarto schronisko dla starych służących, ufundowane przez Józefę i Franciszka Żyszkiewiczów. W zakładzie mieszkało 10 osób, które prowadziły go samodzielnie, bez udziału personelu. Najuboższym wypłacano zapomogi na zakup żywności, którą mieszkańcy schroniska samodzielnie kupowali i przygotowywali. Kuratelę nad podopiecznymi sprawował opiekun z ramienia Lubelskiego Towarzystwa Dobroczynności ${ }^{45}$.

Zainteresowanie i współczucie opinii publicznej wywoływała trudna sytuacja starszych nauczycielek, niezdolnych do dalszej pracy. Wiele z nich zarabiało zbyt mało, by zgromadzić środki na utrzymanie się w okresie starości, toteż po zakończeniu kariery znajdowały się nierzadko w tragicznym położeniu ${ }^{46}$. Założenie przytułku dla byłych nauczycielek było jednak, z powodu braku funduszy, trudnym przedsięwzięciem. Po latach starań schronienie takie powstało w 1880 r. w Warszawie ${ }^{47}$. Kilkakrotnie zmieniało siedzibę - najpierw mieściło się przy ul. Żurawiej, później przy Kruczej, następnie Zielnej, by w 1902 r. otrzymać nowy dom w Zielonce. Mogło w nim zamieszkać 60 kobiet $^{48}$. Schronisko mające ciągłe trudności finansowe utrzymywało się z ofiar pieniężnych prywatnych darczyńców, zbiórek, a także wpłat pensjonariuszek. Mimo starań działaczy społecznych i apeli w prasie zakładu, w którym znalazłyby schronienie i opiekę byłe nauczycielki, nie zdołano utworzyć w Łodzi ${ }^{49}$.

Wymienione wyżej placówki stałej opieki nad osobami starymi działały głównie na zasadach filantropijnych. Innego rodzaju instytucją był przytułek dla starców założony

42 Ibidem, s. 115; E. Mazur, Dobroczynność..., op. cit., s. 60-61.

43 Kalendarz... na rok 1913, op. cit., s. 493.

${ }^{44}$ Dla najbiedniejszych dzieci miasta Kielc w 40-letnia rocznicę działalności Kieleckiego Towarzystwa Dobroczynności, oprac. M. Zawadzki, Kielce 1913, s. 13, 16. Podobne stowarzyszenie działało także w Radomiu.

45 C. Kępski, Lubelskie Towarzystwo Dobroczynności (1815-1952), Lublin 2011, s. 76.

${ }^{46}$ L. Krzywicki, Kasa emerytalna dla osób pracujacych na polu wychowawczym, „Nowe Tory” 1914, nr 1-2, s. 70-78. O schronisku nauczycielek wielokrotnie pisano na łamach „Kroniki Rodzinnej”.

47 Liberum veto, „Prawda” 1882, nr 28, s. 333.

48 Schronienie dla nauczycielek, „Bluszcz” 1902, nr 44, s. 523-524; Schronisko nauczycielek w Zielonce, „Przegląd Pedagogiczny” 1902, nr 24, s. 287-288.

49 Schronisko dla nauczycieli emerytów w Lodzi, „Nowe Tory” 1909, z. 3, s. 271. 
w Liskowie w guberni kaliskiej. Był przykładem lokalnej inicjatywy o charakterze samopomocowym, przejawem solidarności społecznej i zdolności organizacyjnych wiejskiej społeczności, starającej się samodzielnie rozwiązać trudne problemy socjalne ${ }^{50}$. Inicjatorem zakładu był ks. Wacław Bliziński, dom na ten cel przekazał jeden ze starszych włościan, Antoni Majdański. Budynek składał się z dwóch izb, kuchni i sieni, przylegał doń ogród. Przebywający w przytułku starcy mieli być utrzymywani z alimentów wypłacanych przez dzieci. Nad przekazywaniem notarialnie ustalonych kwot miał czuwać nadzór przytułku, w skład którego wchodzili najbardziej poważani miejscowi gospodarze i proboszcz ${ }^{51}$. Starcy, którzy czuli się na siłach, mogli wykonywać drobne prace w ogrodzie albo przygotowywać nici dla warsztatów tkackich. Słabością przytułku było to, że nie mogli w nim być umieszczani ludzie, którzy nie posiadali alimentów. Liczono, że w przyszłości uzyskanie zapisów na rzecz przytułku i zgromadzenie środków z pracy pensjonariuszy spowoduje, że możliwe będzie przyjmowanie również osób niemających pieniędzy na swoje utrzymanie.

Zapewnienie schronienia dla starców, osób niepełnosprawnych i przewlekle chorych było traktowane w kategoriach tradycyjnych powinności o charakterze religijnym i etycznym. Jednocześnie tendencja do rozbudowy różnorodnych form instytucjonalnej opieki nad ludźmi w okresie starości, zwłaszcza opartych na zasadach samopomocy, była wyrazem dążeń do zbudowania nowoczesnych relacji w życiu społecznym. W niektórych zakładach pensjonariusze wykonywali prace na rzecz placówki, byli włączani do życia lokalnej społeczności. I tak np. Tekla Łubieńska, przebywająca ,jako uboga wdowa w domu schronień" w Radomiu była dozorczynią w miejscowej ochronce dla dzieci $^{52}$.

Nie zmienia to faktu, że w większości zakładów w omawianym okresie relacje oparte były na zasadach filantropii i paternalizmu, którego konstytutywnym elementem było kontrolowanie i ingerowanie w życie podopiecznych. Od starców mieszkających w przytułkach oczekiwano nie tylko posłuszeństwa wobec regulaminu, ale i wdzięczności wobec filantropów (wyrażanej m.in. modlitwą). Jeśli zastanawiano się nad funkcjonowaniem mikroświata przytułków, to w odniesieniu do schronisk dla dzieci, ale raczej nie dla osób starszych. Przyjmowano a priori, że założyciel przytułku ma wyłączne prawo do określania zasad w nim panujących, a mieszkańcy obowiązek respektowania regulaminu. Tylko w nielicznych przypadkach podejmowano próbę wprowadzenia pełnej autonomii podopiecznych; takie dążenia widoczne były np. w lubelskim schronisku dla starych służących. W większości niezależność seniorów mieszkających w przytułkach była znacznie ograniczona. Z zachowanych źródeł wiadomo, że czasami mieszkańcy

\footnotetext{
${ }^{50} \mathrm{Na}$ temat starości i sytuacji ludzi w podeszłym wieku w środowisku wiejskim w ujęciu historycznym, socjologicznym i antropologicznym zob. szerzej: B. Gapiński, Ludzie starzy na wsi polskiej od schytku XIX wieku po rok 1939, Poznań 2014.

51 M. Moczydłowska, Wieś Lisków na podstawie wiadomości zebranych na miejscu, Kalisz 1913, s. 133.

52 Archiwum Główne Akt Dawnych, Rada Główna Opiekuńcza, sygn. 69, k. 4.
} 
przytułków skarżyli się na niewłaściwe traktowanie. Trzeba jednak pamiętać, że warunki bytowe w przeciętnym zakładzie, choć skromne, nie były gorsze niż warunki życia przeciętnej ubogiej rodziny. Kategoria intymności, prywatności nie istniała w całym świecie ubogich, nie tylko w przytułkach. Zapewnione w zakładach własne łóżko, skromne, ale regularne posiłki, opieka higieniczna i medyczna były luksusem, niedostępnym wielu starcom żyjącym pod opieką swych dzieci.

Niniejszy artykuł, ograniczając się głównie do prezentacji różnych placówek tworzonych z myślą o seniorach, zapewniających im różne formy pomocy socjalnej i zdrowotnej, jest próbą zwrócenia uwagi na znaczenie instytucjonalnych form opieki w okresie wkraczania społeczeństwa polskiego w epokę nowoczesną. Stanowi przyczynek w rozważaniach na temat starości, wzorców jej przeżywania, sytuacji osób w podeszłym wieku, warunków ich egzystencji, zasad określania ich społecznej roli. Nie omówiono w nim wielu istotnych kwestii, które zasługują na to, by stać się przedmiotem osobnych analiz. Warto zbadać wiele szczegółowych kwestii w odniesieniu do placówek opieki nad osobami starszymi - np. problem uwarunkowań tworzenia i funkcjonowania takich zakładów (czy powstawały, odpowiadając na realne potrzeby, czy były efektem ,filantropijnej mody", w nikłym stopniu reagującej na rzeczywiste wyzwania, w jakim stopniu modernizowano zasady działania tych placówek, jaki był faktyczny poziom ich usług, jakie relacje łączyły pensjonariuszy, jaka była ich ocena własnej sytuacji), ich wpływu na warunki życiowe seniorów w przestrzeni miast, miasteczek, wsi i całych regionów, z uwzględnieniem specyfiki związanej z kontekstem religijnym, etnicznym, zawodowym, regionalnym etc. Warto zastanowić się nad postawami uczonych, publicystów i lokalnych społeczności wobec przytułków i mieszkających w nich kobiet i mężczyzn.

Wydaje się, że możliwości pogłębienia badań nad sytuacją ubogich starców, pensjonariuszy placówek opiekuńczych na przełomie XIX i XX w., wiążą się z wykorzystaniem nowych strategii badawczych. Warto spojrzeć na działalność przytułków jako placówek, które miały zarazem wspierać, jak i kontrolować oraz modelować zachowania podopiecznych. W analizie takiej zasadne byłoby zastosowanie koncepcji ,instytucji totalnych" Ervinga Goffmana ${ }^{53}$; zakłady dla starców nosiły atrybuty takich instytucji, organizując całość życia swoich podopiecznych, niemal zawsze odcinając ich od społeczeństwa, a nierzadko przyczyniając się w pewnym stopniu do ich infantylizowania i ubezwłasnowolniania. W analizie działalności instytucji opiekuńczych dla seniorów warto wykorzystać także Foucaultowską teorię „urządzania”, opartą na konstytutywnym połączeniu wiedzy-władzy i mechanizmach władzy pastoralnej oraz inne współczesne teorie socjologiczne i filozoficzne ${ }^{54}$.

Refleksje nad placówkami dla ubogich seniorów, trwałością i zmiennością modeli ich działania pomogą odnieść się do szerszego zagadnienia, związanego z tym, 2011

${ }^{53}$ E. Goffman, O pacjentach szpitali psychiatrycznych i mieszkańcach innych instytucji totalnych, Sopot

${ }^{54}$ Ch. Tilly, As Sociology Meets History, New York 1981, s. 78. 
w jakim stopniu w odniesieniu do realiów Kongresówki u progu epoki nowoczesnej można mówić o przemianie w postrzeganiu problemów ludzi starych i wyznaczaniu ich roli i miejsca w społeczeństwie. Pomoże to poznać lepiej z jednej strony problem starości i ludzi starych, z drugiej - okoliczności budowania na ziemiach polskich zalążków nowoczesnego systemu opiekuńczego.

\section{Bibliografia}

\section{Źródła archiwalne}

Archiwum Główne Akt Dawnych, Kancelaria Generał-Gubernatora Warszawskiego, sygn. 7664. Archiwum Główne Akt Dawnych, Rada Główna Opiekuńcza, sygn. 69.

Archiwum Państwowe w Piotrkowie Trybunalskim, Piotrkowskie Towarzystwo Dobroczynności dla Chrześcijan, sygn. 23.

\section{Opracowania}

Badziak K., Walicki J., Żydowskie organizacje społeczne w Lodzi (do 1939 r.), Łódź 2002.

Berner W., Supady J., Działalność lekarsko-społeczna na rzecz zdrowia publicznego w Lodzi w latach 1870-1914, Łódź 2001.

Biuro Informacyjne o nędzy wyjątkowej, „Przegląd Katolicki” 1870, nr 36.

Certowicz M., Opis Włocławka pod względem sanitarnym i hygienicznym, „Zdrowie” 1912, nr 6.

Czas. Kalendarz na rok 1914, Łódź 1913.

Dla najbiedniejszych dzieci miasta Kielc w 40-letnia rocznicę działalności Kieleckiego Towarzystwa Dobroczynności, oprac. M. Zawadzki, Kielce 1913.

Dom Miłosierdzia, „Zwiastun Ewangeliczny” 1904, nr 4.

Dom Miłosierdzia we Włocławku, „Zwiastun Ewangeliczny” 1909, nr 2, s. 52-53.

Dom Schronienia przy Kościele Panny Maryi w Warszawie, „Kronika Rodzinna” 1877, nr 5, s. $69-70$.

Fijałek J., Indulski J., Opieka zdrowotna w Łodzi do roku 1945. Studium organizacyjno-historyczne, Łódź 1990.

Fryze F., Chodorowicz I., Przewodnik po Warszawie i jej okolicach, Warszawa 1873.

Gapiński B., Ludzie starzy na wsi polskiej od schytku XIX wieku po rok 1939, Poznań 2014.

Goffman E., O pacjentach szpitali psychiatrycznych i mieszkańcach innych instytucji totalnych, Sopot 2011.

Gotowicz A., Wpływ warunków pracy na stan zdrowia robotników przemysłowych $w$ guberni piotrkowskiej w 2. połowie XIX i na początku XX w., „Roczniki Dziejów Społecznych i Gospodarczych" 2013, t. LXXIII, s. 123-152.

Grendyszyński L., Opieka nad biednymi i domy schronienia, „Ateneum” 1897, t. III, z. 8.

Grotowski Ż., Rozwój zakładów dobroczynnych w Warszawie, Warszawa 1910.

Gryciuk A., Rozwój przestrzenny osady fabrycznej w Żyrardowie w latach 1829-1916, „Rocznik Mazowiecki” 1976, nr 7, s. 127-166.

Gundlach R., Dom Miłosierdzia, „Zwiastun Ewangeliczny” 1898, nr 8.

Hanecki M., Z dziejów warszawskiej stużby zdrowia w l. 1863-1900, w: Warszawa popowstaniowa 1864-1918, red. S. Kalabiński, R. Kołodziejczyk, Warszawa 1968, s. 105-113. 
Kabacińska K., Ratajczak K., Obraz starości w piśmiennictwie polskim od czasów średniowiecza po wiek XVIII, w: Starość w perspektywie studiów pedagogicznych, red. A. Tokaj, Leszno 2008, s. $13-30$.

Kalendarz informacyjno-encyklopedyczny na rok zwyczajny 1913, Warszawa 1913.

Kalendarz informacyjno-encyklopedyczny na rok zwyczajny 1914, Warszawa 1914.

Kalendarz ziemi radomskiej, Radom 1912.

Kalniuk T., Mityczni obcy: dzieci i starcy w polskiej kulturze ludowej przełomu XIX i XX wieku, Toruń 2014.

Kępski C., Lubelskie Towarzystwo Dobroczynności (1815-1952), Lublin 2011.

Kłaczkow J., Historia parafii ewangelicko-augsburskiej w Radomiu, Torun 2005.

Krzywicki L., Kasa emerytalna dla osób pracujacych na polu wychowawczym, „Nowe Tory” 1914, nr 1-2, s. 70-78.

Liberum veto, „Prawda” 1882, nr 28.

Ludzie starzy i starość na ziemiach polskich od XVIII do XXI wieku (na tle porównawczym), t. I-II, red. A. Janiak-Jasińska, K. Sierakowska, A. Szwarc, Warszawa 2016.

Markiewiczowa H., Działalność opiekuńczo-wychowawcza Warszawskiego Towarzystwa Dobroczynności 1814-1914, Warszawa 2002.

Mazur E., Dobroczynność w Warszawie w XIX wieku, Warszawa 1999.

Mazur E., Opieka dobroczynna nad starcami w Warszawie $w$ drugiej polowie XIX wieku, „Kwartalnik Historii Kultury Materialnej" 2010, nr 58, z. 1.

Mazur E., Szpitale w Królestwie Polskim w XIX wieku, Warszawa 2008.

Mazurek M.H., Powstanie i rozwój ukrytych zgromadzeń bt. Honorata Koźmińskiego w latach 1874-1908, Sandomierz 2009.

Moczydłowska M., Wieś Lisków na podstawie wiadomości zebranych na miejscu, Kalisz 1913.

Niemiłosierne miłosierdzie, „Kronika Rodzinna” 1896, nr 8.

Nawrot-Borowska M., „Życie dtugie i starość zdrowa”: w świetle poradników z zakresu higieny i lecznictwa z II polowy XIX i początków XX wieku, w: Historyczno-społeczne aspekty starzenia się i starości, red. M. Stawiak-Ososińska, A. Szplit, Kielce-Włocławek 2014, s. 38-64.

Papierowski A.J, Okoliczności utworzenia w Płocku Towarzystwa Dobroczynności i jego działalność do wybuchu I wojny światowej, „Notatki Płockie” 2009, nr 1.

Puś W., Żydzi w Łodzi w latach zaborów 1793-1914, Łódź 2003.

Pytlas S., Łódzka burżuazja przemysłowa w latach 1864-1914, Łódź 1994.

Roczne sprawozdanie z czynności Biura Informacyjnego o nędzy wyjątkowej od I-go stycznia 1879 r., po I-wszy stycznia 1880 r., „Przegląd Katolicki” 1880, nr 12.

Schronienie dla nauczycielek, „Bluszcz” 1902, nr 44, s. 523-524.

Schronisko dla nauczycieli emerytów w Łodzi, „Nowe Tory” 1909, z. 3.

Schronisko nauczycielek w Zielonce, „Przegląd Pedagogiczny” 1902, nr 24, s. 287-288.

Sempołowska S., Z dna nędzy, w: Publicystyka społeczna, red. Ż. Kormanowa, Warszawa 1960.

Silva Rerum, „Kronika Rodzinna” 1891, nr 4, 8.

Sosnowska J., Działalność socjalna i opiekuńczo-wychowawcza Łódzkiego Chrześcijańskiego Towarzystwa Dobroczynności (1885-1940), Łódź 2011.

Sprawozdanie roczne z naszych zakładów dobroczynnych warszawskich, „Zwiastun Ewangeliczny” 1907, nr 6, s. 177-179.

Stampfer S., Nowoczesna opieka społeczna i samotni seniorzy: dzieje żydowskich domów starców, w: Ludzie starzy i starość na ziemiach polskich od XVIII do XXI wieku (na tle porównawczym), t. I, red. A. Janiak-Jasińska, K. Sierakowska, A. Szwarc, Warszawa 2016.

Stawiak-Ososińska M., The History of Old Age in Poland (Outline), w: Situation, Education and Activation of Elderly People in Europe, red. M. Stawiak-Ososińska, S. Chrost, Kielce 2014. 
Stella-Sawicki J., Czerstwa starość, czyli jak zachować zdrowie do późnego wieku, Warszawa 1901.

Tilly Ch., As Sociology Meets History, New York 1981.

Tomaszewicz A., Dobroczynność w guberni kaliskiej 1864-1914, Łódź 2010.

Towarzystwo opieki nad nieuleczalnymi chorymi, „Zdrowie” 1898, z. 5.

Urbanek B., Idea opieki nad chorym na ziemiach polskich w latach 1809-1914, Wrocław 2001.

Urbanek B., Medycyna a starość i choroby ludzi w podeszłym wieku na przełomie XIX i pierwszego pótwiecza XX wieku (zarys problematyki i potrzeby badawcze), w: Ludzie starzy i starość na ziemiach polskich od XVIII do XXI wieku (na tle porównawczym), t. I, red. A. Janiak-Jasińska, K. Sierakowska, A. Szwarc, Warszawa 2016, s. 83-95.

Wejssel A., W sprawie działalności sanitarnej gmin stów kilka, „Zdrowie” 1912, nr 7.

Wścieklica W., Państwowe kasy ubezpieczenia robotników na wypadek starości i nieudolności do pracy oraz nowe projekty przymusowego w nim udzialu we Francyi, Anglii i Niemczech, „Ateneum" 1888 , t. IV, z. 10, s. 139-158, z. 11, s. 300-320.

Zaktad dla kalek siostry Julii, „Kronika Rodzinna” 1895, nr 7, s. 194-196.

Zawadzki J., Potrzeby naszych miast i miasteczek. Miasta nasze w świetle ankiety, „Zdrowie” $1912, \mathrm{nr} 3,6,7$. 